\title{
Shining a light on the loss of rheophilic fish habitat in lowland rivers as a forgotten consequence of barriers and its implications for management
}

Birnie-Gauvin, Kim; Aarestrup, Kim; Riis, Torsten M. O. ; Jepsen, Niels; Koed, Anders

Published in:

Aquatic Conservation: Marine and Freshwater Ecosystems

Link to article, DOI:

10.1002/aqc. 2795

Publication date:

2017

Document Version

Peer reviewed version

Link back to DTU Orbit

Citation (APA):

Birnie-Gauvin, K., Aarestrup, K., Riis, T. M. O., Jepsen, N., \& Koed, A. (2017). Shining a light on the loss of rheophilic fish habitat in lowland rivers as a forgotten consequence of barriers and its implications for management. Aquatic Conservation: Marine and Freshwater Ecosystems, 27(6), 1345-1349. https://doi.org/10.1002/aqc.2795

\section{General rights}

Copyright and moral rights for the publications made accessible in the public portal are retained by the authors and/or other copyright owners and it is a condition of accessing publications that users recognise and abide by the legal requirements associated with these rights.

- Users may download and print one copy of any publication from the public portal for the purpose of private study or research.

- You may not further distribute the material or use it for any profit-making activity or commercial gain

- You may freely distribute the URL identifying the publication in the public portal 


\section{Shining a light on the loss of rheophilic fish habitat in lowland rivers as a forgotten consequence of barriers and its implications for management}

\author{
In press in Aquatic Conservation: Marine and Freshwater Ecosystems \\ as a Short Communication
}

Kim Birnie-Gauvin ${ }^{1}$, Kim Aarestrup ${ }^{1}$, Thorsten M. O. Riis ${ }^{2}$, Niels Jepsen ${ }^{1}$, Anders Koed ${ }^{1}$

itute of Aquatic Resources, Section for Freshwater Fisheries Ecology, Technical University of Denmark, Vejlsøvej 39, 8600 Silkeborg, Denmark

${ }^{2}$ Limfjord Council, Stigsborg Brygge 5, 9400 Nørresundby, Denmark

Author for correspondence: K. Birnie-Gauvin, kbir@aqua.dtu.dk

Running title: Habitat loss as a forgotten consequence of barriers 


\section{Abstract}

48 1. The majority of rivers around Europe have been modified in one way or another, and no

49 longer have an original, continuous flow from source to outlet. The presence of weirs and dams

50 has altered habitats, thus affecting the wildlife that lives within them. This is especially true for

51 migrating rheophilic fish species, which in addition to safe passage depend on gradient and fast

52 flowing waters for reproductive success and early development.

53 2. Thus far, research has focused on investigating the impacts of weirs and dams on fish passage,

54 with less attention paid to the loss of habitat entrained by such infrastructures. The loss of

55 rheophilic habitat is particularly important in lowland streams, where gradient is limited, and

56 dams and weirs can be constructed with less effort.

57 3. Denmark is considered a typical lowland country, where the landscape around streams and

58 rivers has been modified by agriculture and other human activities for centuries, leaving

59 management practitioners wondering how much change is acceptable to maintain sustainable

60 fish populations and fisheries practices.

61 4. With examples from Denmark, we attempt to conceptualize the loss in habitat as a result of

62 barriers in lowland streams and rivers, and the repercussions that such alterations may have on

63 rheophilic fish populations. Furthermore, we emphasize the need for management to address

64 habitat loss and its related consequences concurrently with the improvement of fish passage.

65

66 Keywords: river, stream, fish, river management, catchment management, indicator species,

67 hydropower, impoundment

68

69 


\section{Introduction}

71 The presence of barriers (such as weirs, dams and culverts) in rivers has grown immensely in the

72 last centuries. These barriers are most often put in place to serve human needs, such as to

73 generate electricity (Welcomme, 1995), though fish farming, irrigation and flood control are also

74 common (Jungwirth, 1998; Jungwirth, Muhar, \& Schmutz, 2000). When barriers were first

75 established, the potential detrimental impacts to the surrounding environment were not

76 considered (Hunt, 1988), but it quickly became apparent that they had severe consequences to

77 river ecosystems and the organisms that live within them (e.g., Aarestrup \& Koed, 2003;

78 Alexandre \& Almeida, 2010; Dynesius \& Nilsson, 1994; Junge, Museth, Hindar, Kraabøl, \&

79 Asbjørn Vøllestad, 2014; Koed, Jepsen, Aarestrup, \& Nielsen, 2002).

80 Many countries lack a complete inventory of water barriers and those that do typically

81 register large barriers only (e.g., the United States National Inventory of Dams for dams above

82 10m). In Denmark, the Ministry of Environment and Food has recently generated an inventory of

83 barriers to implement the EC Waterframe Directive (Council of the European Communities,

84 2000). Although quite comprehensive, even this inventory is unlikely to account for all Danish

85 barriers given that smaller weirs and especially culverts often remain unregistered. While

86 freshwater management have remedied some of the negative consequences of barriers associated

87 with fish passage (e.g., through fish ladders, fish pass etc.), most of the habitat changes due to

88 damming are still present and thus still threaten stream and river ecosystem sustainability. The

89 need to take action is pressing given that riverine ecosystems are in the poorest condition of all

90 ecosystems across the globe (WWF, 2016). To date, there has been tremendous focus on the

91 impacts of barriers on fish passage (both upstream and downstream movements; e.g., Aarestrup

$92 \&$ Koed, 2003), and finding ways to establish minimal flow to sustain fluvial habitat (Rood et al., 
93 2005). While this approach has merit for management, it ignores some basic problems: (1) it

94 does not account for the loss of habitat in the resulting "ponded" zone that results from

95 damming, and (2) it typically ignores the small-scale migrations and movements of less known

96 species (Larinier, 2001). Moreover, current management schemes tend to neglect effects on other

97 aquatic organisms, such as plants and invertebrates, which are also affected by the presence of

98 obstacles (Merritt \& Wohl, 2005, Palmer, Arensburger, Botts, Hakenkamp, \& Reid, 1995).

99 Here, we briefly describe the important consequences of barriers for rheophilic fish

100 species (i.e., species that live in fast-moving, oxygen-rich water), with greater focus on (1)

101 quantity of habitat lost due to a loss in gradient, and (2) lowland streams/rivers given that

102 gradient is a limiting factor for rheophilic fish reproduction and development in such

103 watercourses. We attempt to conceptualize the loss in habitat as a result of barriers, and present a

104 "quick and dirty" method that could be applied to management scenarios which aim to restore

105 the river continuum and natural habitats for rheophilic fish species.

106

107 Habitat changes as a consequence of barriers

108 Barriers result in fragmentation and decoupling of hydrological, geomorphological and

109 ecological aspects of a river, thereby modifying habitat and restricting movement between them

110 (Lucas \& Baras, 2000; McCluney et al., 2014; Nilsson, Reidy, Dynesius, \& Revenga, 2005; Poff

111 et al., 1997; Ward \& Stanford, 1983, 1995). Specifically, the upstream section becomes a

112 "ponded zone" and the length of this zone depends on the height of the dam and the watercourse

113 gradient (Petts, 1984; Poff et al., 1997; Stanford et al., 1996; Figure 1). In turn, this completely

114 changes the river habitat upstream of the barrier, such as increasing homogeneity of substrates

115 and vegetation (Nilsson \& Jansson, 1995; Poff, Olden, Merritt, \& Pepin, 2007), increasing depth, 
116 reducing current speed, reducing oxygenation, causing sedimentation and changing water

117 temperatures (Petts, 1984; Poff \& Hart, 2002). The downstream habitat also becomes altered, but

118 for the purpose of this paper, we focus primarily on the upstream geomorphological changes

119 induced by barriers.

\section{Lowland streams and rivers: case studies from Denmark}

122 In lowland streams, the areas with relatively high gradients are preferentially selected to

123 construct barriers because of their greater relative potential for energy (Hoffman \& Dunham,

124 2007). Damming effects also vary depending on the size of the watercourse and the location of

125 the dam. Generally, a dam located closer to the source of a river will have fewer repercussions

126 than one located further downstream (Figure 1), because the gradient of the river is typically

127 greater in the upper regions, and therefore a smaller proportion of the watercourse is affected by

128 the damming. Furthermore, upstream parts of a river tend to be narrower than downstream

129 sections, thus the total damming impacts are considerably lower when a barrier is upstream

130 (Figure 1), though may still have important consequences for local species.

131 In Denmark, a country consisting solely of lowland landscapes, rivers are typically small,

132 and have smaller gradients than those from more mountainous countries. While a river in

133 Norway, for example, can easily provide a drop of 500m, even the larger Danish rivers typically

134 begin below 100m above sea level. Large gradients are therefore a limited resource in Denmark.

135 Nonetheless, much of the wildlife in Danish rivers relies on these scarce habitats (especially

136 rheophilic fish), making them especially important to protect. Within lowland rivers, the areas

137 where the gradient is (relatively) large, there is greater potential for harnessing water power,

138 often leading to the establishment of more than a single dam throughout the river course. For 
example, River Grejs (Vejle, Denmark) runs for approx. $15 \mathrm{~km}$, and has a total drop of 55m from

140 source to outlet, where a total of 11 dams were established by 1986.

An altered flow regime caused by dams affects the wildlife present, typically reducing

142 biodiversity (Bunn \& Arthington, 2002; Power, Dietrich, \& Finlay, 1996) and population size of

143 migratory species (Hubbs \& Pigg, 1976; Zhong \& Power, 1996). This is especially true for

144 rheophilic species (Hoffman \& Dunham, 2007). Hence, the increase in water level (i.e.,

145 increased depth) and current decrease may be used as indicators of the loss in geomorphological

146 variability and thus a river's ability to maintain biodiversity, as well as a rough measure of

147 potential rheophilic habitat loss. This is important because a relatively large proportion of species

148 that inhabit freshwater streams require relatively fast flowing and oxygen-rich water with varied

149 substrate conditions in order to thrive; the most common threat to freshwater species (i.e., fish,

150 amphibians, reptiles, mammals and birds) is habitat loss and degradation from anthropogenic

151 activities (Freyhof \& Brooks, 2011).

152 Given the extent of dam establishment in some lowland rivers, much of what used to

153 constitute adequate habitats for these species is no longer available. For example, habitat quality

154 indicator species in Danish rivers, such as Atlantic salmon (Salmo salar) and brown trout (Salmo

155 trutta), spawn and grow (during early life stages) in stretches where habitat is typified as riffle

156 areas with gravel or cobble substrate, with low gradients (Gibson, 1993, Gibson, Bowlby, \&

157 Amiro, 2008). Dammed rivers reduce the availability of such stretches, and have been shown to

158 reduce overall salmonid populations (Welcomme, 1985).

159 Recognizing the consequences of barriers on freshwater ecosystems has led to the pursuit

160 of mitigation strategies. For example, some municipal and governmental agencies have put in

161 place new infrastructures to address environmental concerns (e.g., periodic high flows, fish 
162 ladders; Auer, 1996). A common approach is the installation of nature-like fish passes. These

163 bypasses can be useful in allowing fish to move upstream and downstream of a barrier (e.g.,

164 Calles \& Greenberg 2005) but do not remedy the underlying habitat alterations caused by

165 barriers (Dadswell, 1996), and have been found to have limited success (Bunt, Castro-Santos, \&

166 Haro, 2012). Recent evidence suggests that dam removal provides an efficient management tool

167 for ecological restoration of freshwater ecosystems (reviewed in Bednarek, 2001), and should be 168 considered where possible. In fact, complete dam removal restores habitat quality, quantity and 169 connectivity, thus restoring previously lost habitat (Pess, McHenry, Beechie, \& Davies, 2008),

170 enabling rheophilic fish populations to re-establish and also enabling fish to migrate (both on

171 small and large scales), regardless of how much knowledge we have on a species.

\section{Conceptualizing habitat loss: applications for management}

174 In Table 1, we provide data for three Danish rivers that vary in size from $3 \mathrm{~m}$ to $40 \mathrm{~m}$ in width and 175 from $20 \mathrm{~km}$ to $149 \mathrm{~km}$ in length. We present the total drop from spring to outlet, the summed drop

176 resulting from barriers, the total length of the river, and the summed length of the ponded zone.

177 This data was then used as a rough estimate of vertical and horizontal habitat loss (Table 1). This

178 specific information was chosen given that it is typically easily accessed and could easily be

179 applied to management strategies. We acknowledge that the habitat loss may not be proportional

180 to the loss in gradient (as this approach suggests). In fact, the relationship between habitat loss

181 and gradient is likely more complex, especially if barriers are present further upstream, but this

182 approach has merit to rapidly address some of the management concerns we are currently facing.

183 This approach shows that a large proportion of the potential rheophillic habitat is lost in

184 the ponded zones (Table 1). River Gudenaa, the longest river in Denmark, was historically one of 
185 the most important Danish rivers with large populations of anadromous salmonids. It has seven

186 barriers in the main stem predominantly for hydro power generation, yielding a total relative loss

187 of the potential spawning and juvenile development habitat of $36 \%$ (Table 1). This loss increases

188 to approx. $60 \%$ if we exclude the upper $10 \%$ of the watercourse where the river is narrow, the

189 gradient is significantly larger, and salmon production is historically non-existent. The smaller

190 Rivers Villestrup and Omme, on the other hand, have barriers established for fish farming or old

191 watermill purposes, but nonetheless result in a similar loss in habitat. Furthermore, this estimated

192 habitat loss is likely underestimated at fish farm sites, because the stretch of the river between a

193 weir and the outlet of a fish farm is often several hundreds of meters apart, with very little water

194 flow during a large part for the year. The habitat quality in these stretches is limited as a

195 consequence of the reduced water flow alone, but may also represent an area of high predation

196 (Jepsen, Aarestrup, Økland, \& Rasmussen, 1998; Poe, Hansel, Vigg, Palmer, \& Prendergast,

197 1991; Ruggerone, 1986).

198 The three rivers discussed in the above paragraph run mainly through agricultural land.

199 However, rivers running through urban areas may be subjected to even more severe habitat loss

200 (Birnie-Gauvin, Peiman, Gallagher, de Bruijn, \& Cooke 2016). River Mølleaa is approx. 13km

201 long, and flows through Northern Copenhagen into the Øresund strait. The river has nine dams,

202 which together remove an estimated $75 \%$ of the river gradient. There is virtually no natural

203 gradient left, and thus no adequate habitat for rheophilic species.

\section{Conclusions}

206 The productive potential of rheophillic species in lowland freshwater rivers is greatly reduced by

207 the presence of dams and weirs. Typical management interventions aim to address issues 
208 concerning fish passage, but often omit to consider the habitat that has already been lost as a

209 result of barriers for which we lack empirical data (Abell, 2002). Given the relatively limited

210 gradient available in Danish rivers (and in lowland rivers across the world in general) and the

211 potential habitat loss associated with the latter, the overall effects of water barriers on habitat

212 should be included in assessments of watercourses. These actions should be undertaken

213 concurrently with the improvement of fish passage and other typical management-related

214 challenges. To improve the state of regulated lowland rivers may mean that many of these river

215 obstacles need to be removed in order to reinstate the former gradient and habitat, which may re-

216 establish proper fauna passage in itself.

217 The purpose of this paper was to shine a light on a problem that is often ignored in

218 traditional fish management to this day: rheophilic habitat loss resulting from barriers. Too often,

219 the focus of management is on fish passage alone, ignoring other important effects of damming.

220 This may be particularly true for lowland rivers. Given the number of dams and weirs in rivers

221 across the world, we acknowledge that acquiring complete knowledge on habitat loss and fish

222 passage is a daunting task. However, if the majority of rheophilic-appropriate habitat is lost,

223 improving fish passage may be pointless. We therefore suggest the use of a "quick and dirty"

224 method (Table 1) to evaluate the potential loss in habitat as a result of barriers. This approach

225 may provide managers with an improved overview of the state of rivers, and allow for better

226 management strategies to be implemented. Further studies should be undertaken to evaluate the

227 validity of the approach.

228

229 Acknowledgements 
This research was funded by the Danish rod and net fish license funds and the European Union

(AMBER project).

232

233

234

235

236

237

238

239

240

241

242

243

244

245

246

247

248

249

250

251

252

253

254

255

256

257

258

259

260

261

262

263

264

265

266

\section{References}

Aarestrup, K., \& Koed, A. (2003). Survival of migrating sea trout (Salmo trutta) and Atlantic salmon (Salmo salar) smolts negotiating weirs in small Danish rivers. Ecology of Freshwater Fish, 12, 169-176.

Abell, R. (2002). Conservation biology for the biodiversity crisis: a freshwater follow-up. Conservation Biology, 16, 1435-1437.

Alexandre, C. M., \& Almeida, P. R. (2010). The impact of small physical obstacles on the structure of freshwater fish assemblages. River Research and Applications, 26, 977-994.

Auer, N.A. (1996). Response of spawning lake sturgeons to change in hydroelectric facility operation. Transactions of the American Fisheries Society, 125, 66-77.

Bednarek, A.T. (2001). Undamming rivers: a review of the ecological impacts of dam removal. Environmental Management, 27, 803-814.

Birnie-Gauvin, K., Peiman, K.S., Gallagher, A.J., de Bruijn, R., \& Cooke, S. J. (2016). Sublethal consequences of urban life for wild vertebrates. Environmental Reviews, 24, 416-425.

Bunn, S. E., \& Arthington, A. H. (2002). Basic principles and ecological consequences of altered flow regimes for aquatic biodiversity. Environmental management, 30, 492-507.

Bunt, C. M., Castro-Santos, T., \& Haro, A. (2012). Performance of fish passage structures at upstream barriers to migration. River Research and Applications, 28, 457-478.

Calles, E. O., \& Greenberg, L. A. (2005). Evaluation of nature-like fishways for re-establishing connectivity in fragmented salmonid populations in the river Emån. River Research and Applications, 21, 951-960.

Council of the European Communities. 2000. Council Directive 200/60/EC of the European Parliament and of the Council of 23 October, 2000 establishing a framework for Community action in the field of water policy. Official Journal of the European Communities L327: 1-73.

Dadswell, M. J. (1996). The removal of Edwards Dam, Kennebec River, Maine: its effects on the restoration of anadromous fishes. Draft environmental impact statement, Kennebec River, Maine (Appendices 1-3, pp. 92). Nova Scotia, CA: Acadia University. 
Dynesius, M., \& Nilsson, C. (1994). Fragmentation and Flow Regulation of River Systems in. Science, 266, 4.

Freyhof, J., \& Brooks, E. (2011). European Red List of Freshwater Fishes. Luxembourg:

Gibson, R. J. (1993). The Atlantic salmon in fresh water: spawning, rearing and production. Reviews in Fish Biology and Fisheries, 3, 39-73.

Gibson, A. J. F., Bowlby, H. D., \& Amiro, P. G. (2008). Are wild populations ideally distributed? Variations in density-dependent habitat use by age class in juvenile Atlantic salmon (Salmo salar). Canadian Journal of Fisheries and Aquatic Sciences, 65, 1667-1680.

Hoffman, R., \& Dunham, J. (2007). Fish-movement ecology in high-gradient headwater streams: its relevance to fish passage restoration through stream culvert barriers. Virginia: US Geological Survey, OFR 2007-1140.

Hubbs, C., \& Pigg, J. (1976). The effects of impoundments on threatened fishes of Oklahoma. Annals of the Oklahoma Academy of Science, 5, 133-177.

Hunt, C. (1988). Down by the river: the impact of federal water projects and policies on biological diversity. Washington DC: Island Press.

Jepsen, N., Aarestrup, K., Økland, F., \& Rasmussen, G. (1998). Survival of radio-tagged Atlantic salmon (Salmo salar L.) and trout (Salmo trutta L.) smolts passing a reservoir during seaward migration. In Lagardere, J. P., Begout Anras, M. L., Claireaux, G. (Eds.), Advances in Invertebrates and Fish Telemetry (pp. 347-353), Netherlands: Springer.

Junge, C., Museth, J., Hindar, K., Kraabøl, M., \& Asbjørn Vøllestard, L. (2014). Assessing the consequences of habitat fragmentation for two migratory salmonid fishes. Aquatic Conservation: Marine and Freshwater Ecosystems, 24, 297-311.

Jungwirth, M. (1998). River continuum and fish migration - Going beyond the longitudinal river corridor in understanding ecological integrity. In Jungwirth, M., Schmutz, M. S., \& Weiss, S. (Eds.), Fish migration and fish bypasses (pp. 127-145). Oxford: Blackwell Science.

Jungwirth, M., Muhar, S., \& Schmutz, S. (2000). Fundamentals of fish ecological integrity and their relation to the extended serial discontinuity concept. Hydrobiologia, 422, 85-97.

Koed, A., Jepsen, N., Aarestrup, K., \& Nielsen, C. (2002). Initial mortality of radio-tagged Atlantic salmon ( Salmo salar L .) smolts following release downstream of a hydropower station. Hydrobiologia, 483, 31-37.

Larinier, M. (2001). Environmental issues, dams and fish migration. FAO fisheries technical paper 419 (pp. 45-89). Rome, Italy. 
Lucas, M. C., \& Baras, E. (2000). Methods for studying spatial behaviour of freshwater fishes in the natural environment. Fish and Fisheries, 1, 283-316.

McCluney, K. E., Poff, N. L., Palmer, M. A., Thorp, J. H., Poole, G. C., Williams, B. S., Williams, M. R., \& Baron, J. S. (2014). Riverine macrosystems ecology: sensitivity, resistance, and resilience of whole river basins with human alterations. Frontiers in Ecology and the Environment, 12, 48-58.

Merritt, D. M., Wohl, E. E. (2005). Plan dispersal along rivers fragmented by dams. River Research and Applications, 22, 1-26.

Nilsson, C., \& Jansson, R. (1995). Floristic differences between riparian corridors of regulated and free-flowing boreal rivers. Regulated Rivers: Research \& Management, 11, 55-66.

Nilsson, C., Reidy, C.A., Dynesius, M., \& Revenga, C. (2005). Fragmentation and flow regulation of the world's large river systems. Science, 308, 405-408.

Palmer, M. A., Arensburger, P., Botts, P. S., Hakenkamp, C. C., \& Reid, J. W. (1995). Disturbance and the community structure of stream invertebrates: patch-specific effects and the role of refugia. Freshwater Biology, 34, 343-356.

Pess, G. R., McHenry, M. L., Beechie, T. J., \& Davies, J. (2008). Biological impacts of the Elwha River dams and potential salmonid responses to dam removal. Northwest Science, 82, 7290.

Petts, G. E. (1984). Impounded rivers: perspectives for ecological management. Chichester, England: John Wiley \& Sons.

Poe, T. P., Hansel, H. C., Vigg, S., Palmer, D. E., \& Prendergast, L. A. (1991). Feeding of predaceous fishes on out-migrating juvenile salmonids in John Day Reservoir, Columbia River. Transactions of the American Fisheries Society, 120, 405-420.

Poff, N. L., Allan, J. D., Bain, M. B., Karr, J. R., Prestegaard, K. L., Richter, B. D., Sparks, R. E., \& Stromberg, J. C. (1997). The natural flow regime. Bioscience, 47, 769-784.

Poff, N. L., \& Hart, D. D. (2002). How dams vary and why it matters for the emerging science of dam removal. BioScience, 52, 659-668.

Poff, N. L., Olden, J. D., Merritt, D. M., \& Pepin, D. M. (2007). Homogenization of regional river dynamics by dams and global biodiversity implications. Proceedings of the National Academy of Sciences, 104, 5732-5737.

Power, M. E., Dietrich, W. E., \& Finlay, J. C. (1996). Dams and downstream aquatic biodiversity: potential food web consequences of hydrologic and geomorphic change. Environmental Management, 20, 887-895. 
Rood, S. B., Samuelson, G. M., Braatne, J. H., Gourley, C. R., Hughes, F. M., \& Mahoney, J. M. (2005). Managing river flows to restore floodplain forests. Frontiers in Ecology and the

Ruggerone, G. T. (1986). Consumption of migrating juvenile salmonids by gulls foraging below a Columbia River dam. Transactions of the American Fisheries Society, 115, 736-742.

Stanford, J. A., Ward, J. V., Liss, W. J., Frissell, C. A., Williams, R. N., Lichatowich, J. A., \& Coutant, C. C. (1996). A general protocol for restoration of regulated rivers. Regulated Rivers: Research and Management, 12, 391-413.

Ward, J. V., \& Stanford, J. A. (1983). The serial discontinuity concept of lotic ecosystems. Dynamics of lotic ecosystems, 10, 29-42.

Ward, J. V., \& Stanford, J. A. (1995). The serial discontinuity concept: extending the model to floodplain rivers. Regulated Rivers: Research \& Management, 10, 159-168.

Welcomme, R. L. (1985). River fisheries. FAO Fisheries Technical Paper 262. Rome, Italy.

Welcomme, R. L. (1995). Relationships between fisheries and integrity of river systems.

Regulated Rivers: Research and Management, 11, 121-136.

WWF. (2016). Living Planet Report 2016: Risk and resilience in a new era. WWF International, Gland, Switzerland.

Zhong, Y., \& Power, G. (1996). Environmental impacts of hydroelectric projects on fish resources in China. Regulated Rivers: Research and Management, 12, 81-98. 
411 Table 1. Conceptualizing rheophilic habitat loss. Using three Denmark rivers, the ratio of the 412 total drop as a result of barriers $(\mathrm{m})$ to the total drop of the river from source to outlet (m) was 413 used as a proxy for vertical habitat loss $(\%)$. The ratio of the summed ponded zones $(\mathrm{km})$ to the 414 total river length $(\mathrm{km})$ was used as a proxy for horizontal habitat loss (\%). This "quick and dirty" 415 approach to estimate habitat loss from barriers provides managers with a low cost and effective 416 method to get a rapid overview of the current state of freshwater streams and rivers, and may enable the implementation of more effective management strategies.

\begin{tabular}{|c|c|c|c|c|c|c|}
\hline $\begin{array}{c}\text { River } \\
\text { (\# of dams) }\end{array}$ & $\begin{array}{l}\text { Total drop } \\
\text { from } \\
\text { source to } \\
\text { outlet (m) }\end{array}$ & $\begin{array}{c}\text { Summed } \\
\text { drop from } \\
\text { barriers (m) }\end{array}$ & $\begin{array}{c}\text { Vertical } \\
\text { habitat loss } \\
(\%)\end{array}$ & $\begin{array}{c}\text { Total } \\
\text { river } \\
\text { length } \\
(\mathbf{k m}) \\
\end{array}$ & $\begin{array}{c}\text { Summed } \\
\text { ponded } \\
\text { zones } \\
(\mathbf{k m}) \\
\end{array}$ & $\begin{array}{c}\text { Horizontal } \\
\text { habitat } \\
\text { loss }(\%)\end{array}$ \\
\hline Villestrup (6) & 22 & 8.8 & 40 & 20.0 & 5.8 & 29 \\
\hline Omme (14) & 75 & 17.7 & 24 & 55.0 & 11.35 & 21 \\
\hline Gudenaa (7) & 69 & 24.9 & 36 & 149.0 & -* & -* \\
\hline
\end{tabular}

* Information not available given that the weirs and dams are too old to accurately estimate the 420 length of ponded zones. 
447 Figure 1. Effects of dams on rivers. Conceptualized diagram of the effects of dams on rivers 448 showing two (A and B) identical weirs (i.e., same stemmed height). Depending on the gradient 449 of the river, the ponded zone differs. As the gradient typically decreases, and the river size 450 increases, from source to outlet, a similar sized weir closer to the outlet will have a larger ponded 451 zone, both in terms of length and surface area. Downward-pointing arrows $(\downarrow)$ represent a 452 decrease.

453

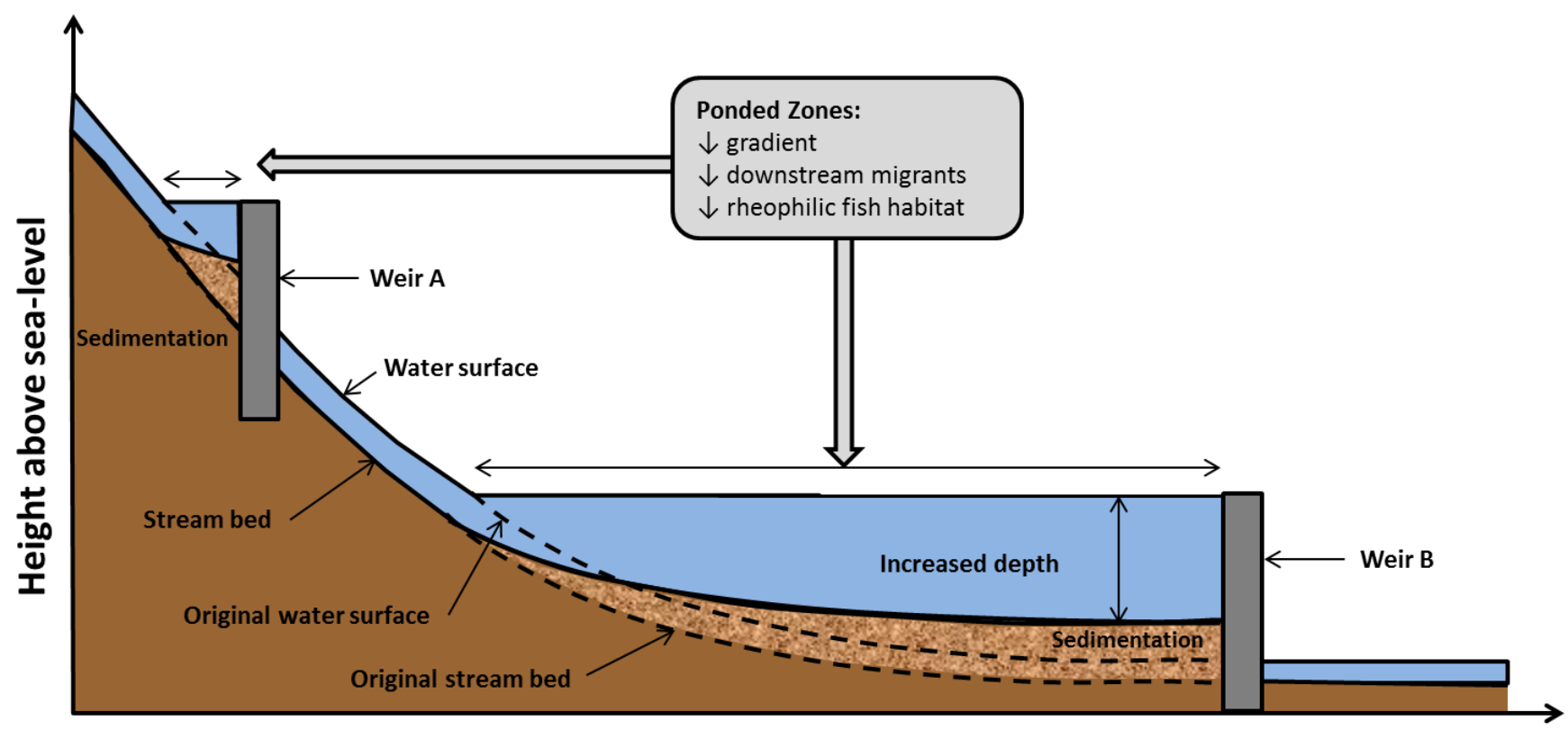

